\title{
Insight \\ Rethinking the Galapagos Islands as a Complex Social-Ecological System: Implications for Conservation and Management
}

\author{
$\underline{\text { José A. González }}^{1}, \underline{\text { Carlos Montes }}^{1}, \underline{\text { José Rodríguez }}^{2}$, and $\underline{\text { Washington Tapia }}^{3}$
}

\begin{abstract}
The Galapagos Islands are among the most renowned natural sites in the world. Unlike other oceanic archipelagos, the ecological and evolutionary processes characteristic of Galapagos have been minimally affected by human activities, and the archipelago still retains most of its original, unique biodiversity. However, several recent reports suggest that the development model has turned unsustainable and that the unique values of the archipelago might be seriously at risk. In response to international concern, UNESCO added Galapagos to the list of World Heritage in Danger in 2007. Our goal was to provide new insights into the origins of the present-day crisis and suggest possible management alternatives. To this end, we re-examined the Galapagos situation from a broad systems perspective, conceptualizing the archipelago as a complex social-ecological system. Past, present, and possible future trends were explored using the resilience theory as a perspective for understanding the dynamics of the system. Four major historical periods were characterized and analyzed using Holling's adaptive cycle metaphor. The current Galapagos situation was characterized as a prolonged series of crisis events followed by renewal attempts that have not yet been completed. Three plausible future scenarios were identified, with tourism acting as the primary driver of change. The current tourism model reduces the system's resilience through its effects on the economy, population growth, resource consumption, invasive species arrival, and lifestyle of the island residents. Opportunities to reorganize and maintain a desirable state do exist. However, strong political and management decisions are urgently needed to avoid an irreversible shift to a socially and environmentally undesirable regime. Key measures to achieve a new sustainability paradigm for Galapagos include modifying traditional practices to produce a more adaptive resilience-based co-management model, adopting a more comprehensive approach to territorial planning, strengthening participative approaches and institutional networks, and promoting transdisciplinary research at the frontiers of social and biophysical sciences.
\end{abstract}

Key Words: adaptive co-management; adaptive cycle; biodiversity conservation; Galapagos Islands; resilience; social-ecological systems; sustainability science

\section{INTRODUCTION}

The Galapagos archipelago is globally renowned for its unique biodiversity and as a natural laboratory for the study of evolution. Unlike other oceanic archipelagos that have been significantly transformed by human activities, the ecological and evolutionary processes characteristic of Galapagos are nearly intact, and the archipelago still retains $95 \%$ of its original species (Bensted-Smith 2002). Thus, it has become an internationally recognized "flagship" area for nature conservation.

The fact that almost $97 \%$ of the land is protected as a National Park, along with the historical absence of aboriginal populations and the late human colonization of the islands, explains why the archipelago has remained in a nearly pristine condition until modern times. These circumstances turn Galapagos into a valuable social-ecological laboratory for research concerning the development of early links and interactions between social and natural systems, as well as a benchmark for monitoring the consequences of human activities on ecosystems and natural processes in the face of global change. Nearly undisturbed landscapes like Galapagos are likely to be increasingly important in the near future as a means to detect human-induced alterations and to test hypotheses at the frontiers of ecology (Thompson et al. 2001). 
However, despite the rigorous conservation policies and legal protection adopted by Ecuador, ecological degradation is occurring at an accelerating rate in Galapagos. Certain development trends and anthropogenic pressures, mostly related to population growth, increasing demand for goods and services, and the arrival of invasive species, are in conflict with the conservation goals and threaten the ecological integrity of the archipelago. These disruptions are driving the transformation of natural ecosystems and the depletion of some populations of native and endemic species, especially on the inhabited islands (Bensted-Smith 2002).

A recent joint mission of UNESCO and the International Union for Conservation of Nature (Karez et al. unpublished report for UNESCO, 28 March 2006) concluded that Galapagos is shifting to an economic development model that is fundamentally at odds with long-term conservation and sustainability interests. Recognizing this critical situation and reflecting the international concern about the fate of the archipelago, UNESCO added Galapagos to the List of World Heritage in Danger in June 2007. Previously, in April 2007, the Ecuadorian government issued an emergency decree declaring the Galapagos Islands at risk and a national action priority.

Underlying this situation is the challenge to make possible the coexistence of the archipelago's unique species and ecosystems with the islands' human population. This is not an easy task because the natural subsystem requires the maintenance of the relative isolation that characterized the islands for all of their pre-human history, whereas the human subsystem demands an increasing flow of goods and services from the continent and among the islands. This controversy between an isolated (claimed by conservation advocates) vs. an increasingly open (demanded by residents and local authorities) archipelago lies at the base of most conflicts in Galapagos (Ospina 2006).

Despite the significant efforts in recent years and the international financial support provided for Galapagos conservation (González 2007), socialecological problems persist and seem to resist resolution, as does the establishment of a firm sustainability plan for the islands. We propose that the situation on the archipelago is not being addressed with a full appreciation of the complexity of the problems. In addition, we suggest that the root of the crisis lies in the fact that social and environmental problems are only being approached from a sectoral point of view. Problems will persist until a comprehensive and integrative framework is developed that is broadly shared by local, national, and international stakeholders.

The study of complex systems has created new tools for modeling interactions between anthropogenic and natural systems (Costanza et al. 1993). Complex systems thinking is being used extensively in this context to analyze linked systems of humans and nature, i.e., social-ecological systems (SESs), at various scales and as a means to bridge social and biophysical sciences (Berkes and Folke 1998, Berkes et al. 2003, Liu et al. 2007). However, there are few documented studies in which this approach has been applied to the context of small islands.

Despite some debate regarding the value of resilience as a descriptive concept or as a boundary object with a broad, vague meaning (Brand and Jax 2007), resilience theory (http://www.resalliance.org ) has been successful in a number of cases as a way of understanding the dynamics and the complexity of SESs. This has resulted in positive communication across disciplines and fostered a constructive exchange of information between science and practice, thus promoting the integration of isolated policies and facilitating the development of innovative methods to achieve sustainable outcomes in various geographical situations (Anderies et al. 2006). In Galapagos, apart from some attempts to analyze the global problems of the archipelago from an integrative perspective (MacFarland and Cifuentes 1996, Bensted-Smith 2002, Watkins and Cruz 2007), resilience-based approaches have rarely been used. In the limited situations in which they have been used, only specific issues have been examined (e.g., Wilkinson et al. 2005, Heylings and Bravo 2007).

Our goal was to provide insight into and new perspectives on the international efforts to overcome the current crisis and to facilitate a transition toward a more sustainable archipelago. We present the concept of the Galapagos Islands as a linked SES and revisit its current situation from a systems approach, using resilience theory as a new perspective (sensu Folke 2006b) from which to understand the dynamics of the archipelago and to organize thought about management options. We approached this process as a series of dependent steps, the first of which was to analyze how historical system dynamics have shaped the current 
system. We then examined recent trends in social and ecological variables that might explain the present crisis. System dynamic models were developed to identify plausible future scenarios and the major drivers of change. Finally, we discuss the particularities of Galapagos as an SES and compare current management practices with those that emerge from a resilience-based approach.

\section{THE GALAPAGOS ISLANDS}

Comprising seven major islands (> $100 \mathrm{~km}^{2}$ ), 11 smaller islands (1-100 $\left.\mathrm{km}^{2}\right)$, and > 120 islets and rocks, Galapagos straddles the equator approximately $960 \mathrm{~km}$ west of mainland Ecuador and $1100 \mathrm{~km}$ south of Costa Rica. The total land area of the archipelago is approximately $7995 \mathrm{~km}^{2}, 97 \%$ of which is protected by the Ecuadorian government as a National Park. Additionally, the Galapagos Marine Reserve, which is the third largest in the world $\left(\sim 133,000 \mathrm{~km}^{2}\right)$, protects the waters within 40 nautical miles of the island group, measured from the base line connecting the outermost points of the islands (Fig. 1). Only five islands are currently inhabited: Santa Cruz, San Cristóbal, Isabela, Floreana, and Baltra. According to the latest population census conducted in 2006, the number of residents in the archipelago approaches 20,000 (Instituto Nacional de Estadística y Censos and Instituto Nacional Galápagos unpublished report: http://www.inec.gov.ec). Approximately $85 \%$ of the people live in the coastal villages of Puerto Ayora (9208 people), Puerto Baquerizo Moreno (5539 people), Puerto Villamil (1570 people), and Puerto Velasco Ibarra (109 people). For a more thorough description of Galapagos and its main biophysical characteristics, refer to the publications of Perry (1984), Bensted-Smith (2002), and Danulat and Edgar (2002). Sociological, institutional, and political aspects of the archipelago are thoroughly treated in the publications of Grenier (2000) and Ospina (2001, 2006).

\section{WHERE DO WE COME FROM? GALAPAGOS HISTORY REVISITED}

\section{Historical profile}

Resilience theory highlights the importance of investigating the historical relationships between societies and their environments. This information is an essential part of understanding the complexity of social-ecological systems (SESs) and identifying the root causes of environmental problems. A careful analysis of historical profiles usually reveals a great deal about current system dynamics and how the system might respond to future change (Walker et al. 2002, Berkes et al. 2003). The history of human-nature relationships in Galapagos is relatively short compared to that of other oceanic archipelagos and spans no more than five centuries. We summarized the historical profile of the archipelago into four major periods: "extractive exploitation," "colonization," "wilderness conservation," and "conservation-development balance" (Table 1).

The first historical period, extractive exploitation, spanned nearly three centuries, from 1535 to 1832 , beginning with the discovery of the islands. This period was marked by the presence of pirates and whalers who found safe anchorage, firewood, and food reserves on the islands. The first alien species were introduced, including goats, rats, and probably some insects and plants (Tye et al. 2002), and the exploitation of giant tortoises began. However, continuous human settlement was delayed, probably because of the isolation, harsh environment, and scarcity of fresh water (Latorre 1999).

The second historical period, colonization, began when the Ecuadorian government took possession of the islands. This period spanned from 1832 to 1959 and was characterized by the establishment of the first permanent human settlements (Latorre 1999). Patterns of extractivism continued during this period, but colonists established closer links with the natural system. The unique native ecosystems began to undergo transformation, especially in the humid highlands of the inhabited islands, where colonists reared livestock and grew crops on the rich volcanic soil. The number of exotic plants and animals increased dramatically, which accelerated the rates of change. It was near the beginning of this period that Charles Darwin visited the archipelago, establishing Galapagos as a premier location for the study of ecology and evolutionary principles.

The third historical period, wilderness conservation, occurred from 1959 to 1998 , mainly as a response to increasing pressure from international organizations to adopt measures that would protect the Galapagos Islands from threats to its biodiversity. The Galapagos National Park (GNP) was established by 
Fig. 1. Map of the location of the Galapagos Islands, showing protected areas and areas used by humans (mostly agricultural zones).

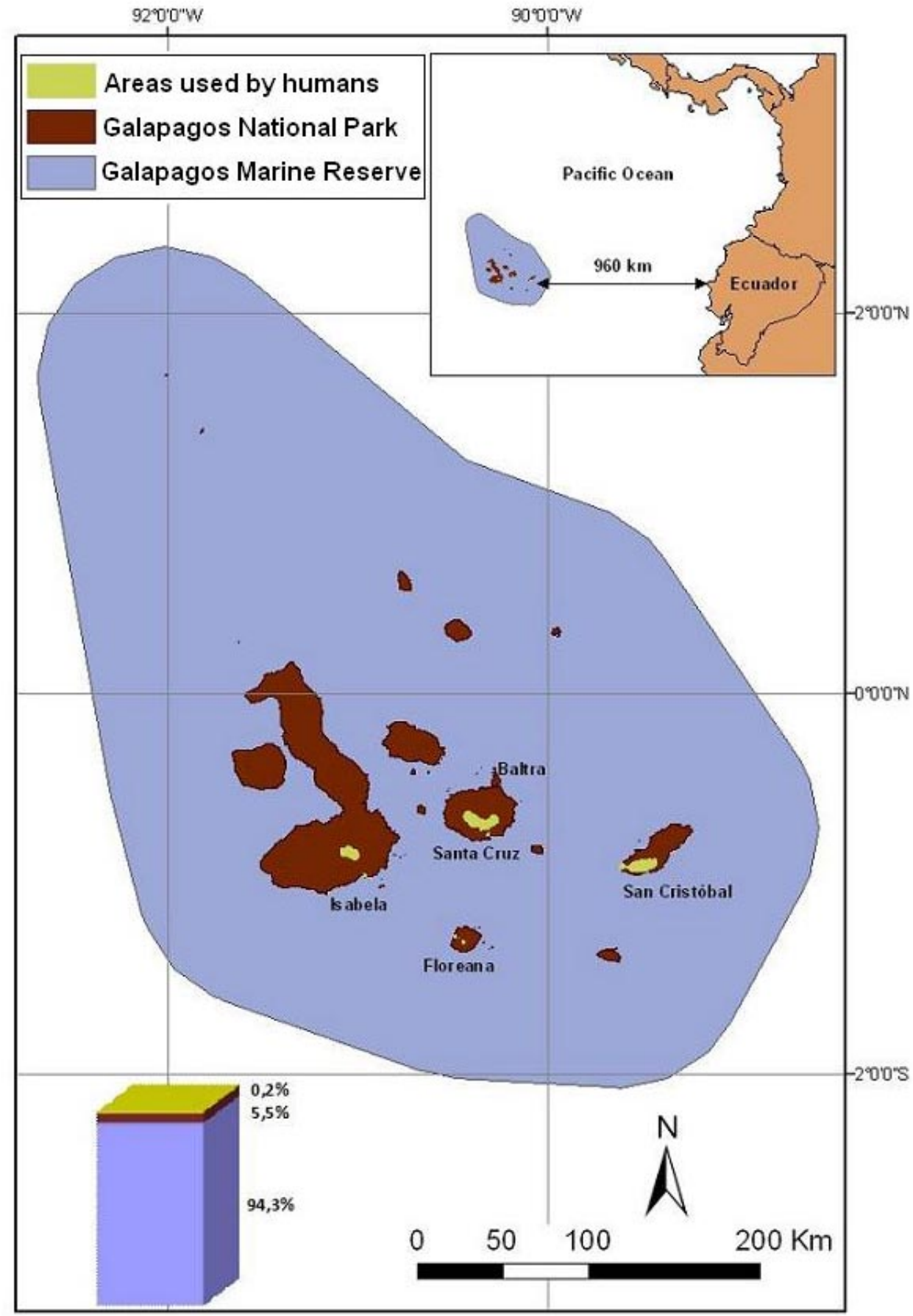


Table 1. Summary of the major historical periods and events that have influenced the self-organization capacity of the Galapagos social-ecological system.

\begin{tabular}{|c|c|c|}
\hline $\begin{array}{l}\text { Major period } \\
\text { (time span) }\end{array}$ & Major events & Social-ecological effects \\
\hline
\end{tabular}

Extractive exploitation (1535-1832)

- Tomás de Berlanga discovered the islands in 1535

- $\quad$ Pirates and buccaneers used the islands as a refuge and a source of water and food (16841790)

- Whalers and fur seal hunters exploited the archipelago (1800s)

Colonization (1832-1959)

Wilderness conservation (1959-1998)
- Ecuador took possession of the archipelago in 1832

- First serious colonization attempt on Floreana Island (1832-1841)

- Charles Darwin visited Galapagos in 1835

- International conflicts for possession of the archipelago

- A special law promoted colonization of the archipelago (1885): several colonization attempts followed

- Exploitation of tuna fishery (1900s)

- International scientific expeditions explored the islands and strongly supported protection of the archipelago (1905-1939)

- U.S. military base established on Baltra Island in 1943
- Exploitation of giant tortoise for fresh meat

- Several populations of giant tortoise depleted (> 200,000 hunted)

- First alien mammals introduced

- Permanent human settlements established on four of the islands

- Native ecosystems of the highlands (Scalesia, Miconia) of San Cristóbal and Floreana islands cleared and transformed by agricultural activities

- Cattle released on the major islands

- Increasing demand for perishable food drove the first wave of new seeds and exotic plants arriving from the mainland

- $\quad$ Alien invasive plants and animals proliferated on the inhabited islands, altering ecological processes and eroding native biodiversity

- After Darwin's work, Galapagos became well known among scientists as a "paradise" for research regarding conservation and evolution

- Increasing international concern about the need to preserve the uniqueness of Galapagos

- Almost $97 \%$ of the islands' territory became protected (the areas that were not yet colonized)

- Charles Darwin Foundation for the Galapagos Islands created in 1959

- $\quad$ Organized cruise-boat tourism began in 1969
- Coordinated efforts to preserve biodiversity began 

Conservation- development balance (1998-present)
- Galapagos Special Law passed in 1998
- Galapagos inspection and quarantine system (SESA-SICGAL) established
- Galapagos Marine Reserve established in 1998; management plan approved in 1999
- Galapagos Regional Plan approved in 2003
- Fourth management plan of the Galapagos National Park approved in 2005
- Galapagos added to UNESCO list of endangered heritage sites in 2007

- The archipelago attained special status: protection, migratory restrictions, quarantine system, and participatory management of the Galapagos Marine Reserve

- $\quad$ Fisheries management improved, but political decisions and social considerations still hindered technical management

- Social conflicts proliferated around the prohibition of long-line fishing and the sea cucumber closed season

- Social discontent with the unfair distribution of benefits derived from tourism

- Locally based tourism began to be promoted the Ecuadorian government to protect all areas that had not yet been colonized. The Charles Darwin Foundation (CDF), an international scientific organization, was also created to conduct research and to advise national authorities regarding the conservation and management of the islands. There were successful efforts to preserve native biodiversity, especially through captive breeding of endangered species and active control of invasive organisms. During this period, conservation policy was guided primarily by international scientists and influenced by foreign institutions.

The declaration of Galapagos as a new province of Ecuador in 1973 opened the door to a wider array of social conflicts characterized by the dialectic between conservation and development objectives. Organized cruise-boat tourism, which began in 1969 and was initially promoted by conservation institutions, and increasing public investment in the islands triggered a phase of economic development. Economic growth stimulated immigration from mainland Ecuador, a progressive abandonment of agricultural lands as the rural population moved to new coastal villages, and a second wave of alien species arrival. These patterns expanded in the early 1980s and 1990s with the development of the lobster and sea cucumber fisheries, which generated a "gold-rush" scenario in the islands (Bremner and Perez 2002).

Increasing social conflicts and ecological degradation led to a fourth historical period, conservation-development balance, that began with the participative elaboration and passing of the Galapagos Special Law (GSL) in 1998. The GSL became a key legal instrument that granted the province special status, including severe migratory restrictions, a new inspection and quarantine system, and a new institutional framework that enhanced ecosystem protection. It was probably the first attempt to tackle the complexity of the problems of Galapagos in their entirety. The GSL created the Galapagos Marine Reserve (GMR), which is provided with an innovative participatory management regime (Heylings and Bravo 2007). The GSL also included several other advanced measures intended to bridge the existing gap between conservation and development interests. The first management plan of the GMR was approved in 1999. A Galapagos Regional Plan was also endorsed in 2003, establishing major guidelines to achieve a balance between economic growth and biodiversity conservation.

\section{Adaptive cycles}

To better understand the sequence of events that helped to shape the present situation, we reviewed the above historical profile using Holling's (2001) adaptive cycle theory. Linked systems of humans and nature are intrinsically dynamic, so cyclic change is an essential characteristic of all SESs (Berkes et al. 2003). This change has been modeled in a classic heuristic model consisting of four 
sequential stages that reflect the cyclic processes of growth, consolidation, release, and reorganization that most systems experience (Holling 2001). The adaptive cycle metaphor has been widely used to recognize changes in system behavior and examine the dynamics and resilience of SESs (Carpenter et al. 2001, Berkes et al. 2003).

Using the accumulation and release of natural, human, or social capital to describe the dynamics of the system and identify different phases of the cycle (Gunderson and Holling 2002, Abel et al. 2006), the history of Galapagos as an SES fit into three complete adaptive cycles and one incomplete one, corresponding to the four major historical periods (Fig. 2). Although this approach has certain limitations and may seem fraught with subjectivity, we think that the result is valuable and helps to identify major periods of collapse and reorganization that led to the present conditions.

The first cycle encompasses most of the first three centuries of human history in the archipelago, with the forward loop characterized by a period of pure extractive exploitation of natural resources and the introduction of the first alien mammal species. The back-loop began when exploited resources became scarce and increasing international interests forced the Ecuadorian government to take possession of the islands and initiate a colonization process. This led to the second adaptive cycle in which the forward loop is characterized by the first successful colonization attempts, with agricultural expansion taking place in the humid highlands of four of the largest islands. The back-loop of collapse and reorganization began in the mid-20th century, when the international scientific community became increasingly aware of the threat to native ecosystems posed by alien invasive species and the effects of overexploitation on some emblematic species, mainly whales, fur seals, and giant tortoises, that were forced to the brink of extinction. Subsequent political decisions adopted by the Ecuadorian government allowed the system to renew and reorganize around the creation of the GNP and the CDF.

This reorganization led to a third adaptive cycle, characterized by an increasing number of organized efforts to preserve native biodiversity. In the forward loop, nature tourism was promoted because it was expected to be closely allied with and contribute to conservation policy, and new public administrative institutions were created and local infrastructure grew. Public and private institutions and networks devoted to conservation gradually expanded and gained more influence during this phase. It is during this forward loop of the cycle that most of the current problems probably originated. Most conservation efforts were conducted without the consideration of local concerns. Some actions were even counter to the wishes or best interests of the local communities, which were often viewed by conservation organizations as a wholly negative influence; for example, several initiatives were proposed to limit public services and promote abandonment of the islands. Not surprisingly, antagonism between conservationists and development advocates grew, a situation that remains at the center of present-day conflicts in the archipelago (Grenier 2000). The back-loop of the cycle began during the 1990s, when the exploitation of coastal fisheries and the expansion of tourism quickly increased the number of immigrants from mainland Ecuador. The overexploitation of fisheries, arrival of new exotic species, and social conflicts among conservation institutions, user groups, and elected local authorities increased during this cycle's back-loop.

A new renewal phase began with the enactment of the GSL and the establishment of the GMR in 1998. The endorsement of a Regional Plan along with Cantonal Strategic Development Plans and the approval of a new Management Plan for the GNP are also part of this reorganization phase, which has not yet been completed.

\section{WHERE ARE WE NOW? THE CRISIS IN FIGURES}

The present Galapagos situation reflects one of the recognized variations in the adaptive cycle whereby reorganization begins, but no structure emerges (Walker et al. 2006). Cross-scale interactions, the loss of natural capital, and continuous external disturbances in the form of political instability hinder innovation. Thus, the system again becomes disordered.

Some of the negative trends, which we describe in the following sections, have not changed despite prominent legal, political, institutional, and management decisions. The data that we present here support the idea that the current situation in Galapagos is the result of a prolonged and unresolved social-ecological crisis that prevents the reorganization of the system and might drive it into a path toward a less desirable state (Fig. 2). 
Fig. 2. Major historical periods and adaptive cycles of renewal in the Galapagos social-ecological system that have led to the present situation in which no structure emerges despite several renewal attempts and there is a clear risk that the system may shift to a qualitatively different state.

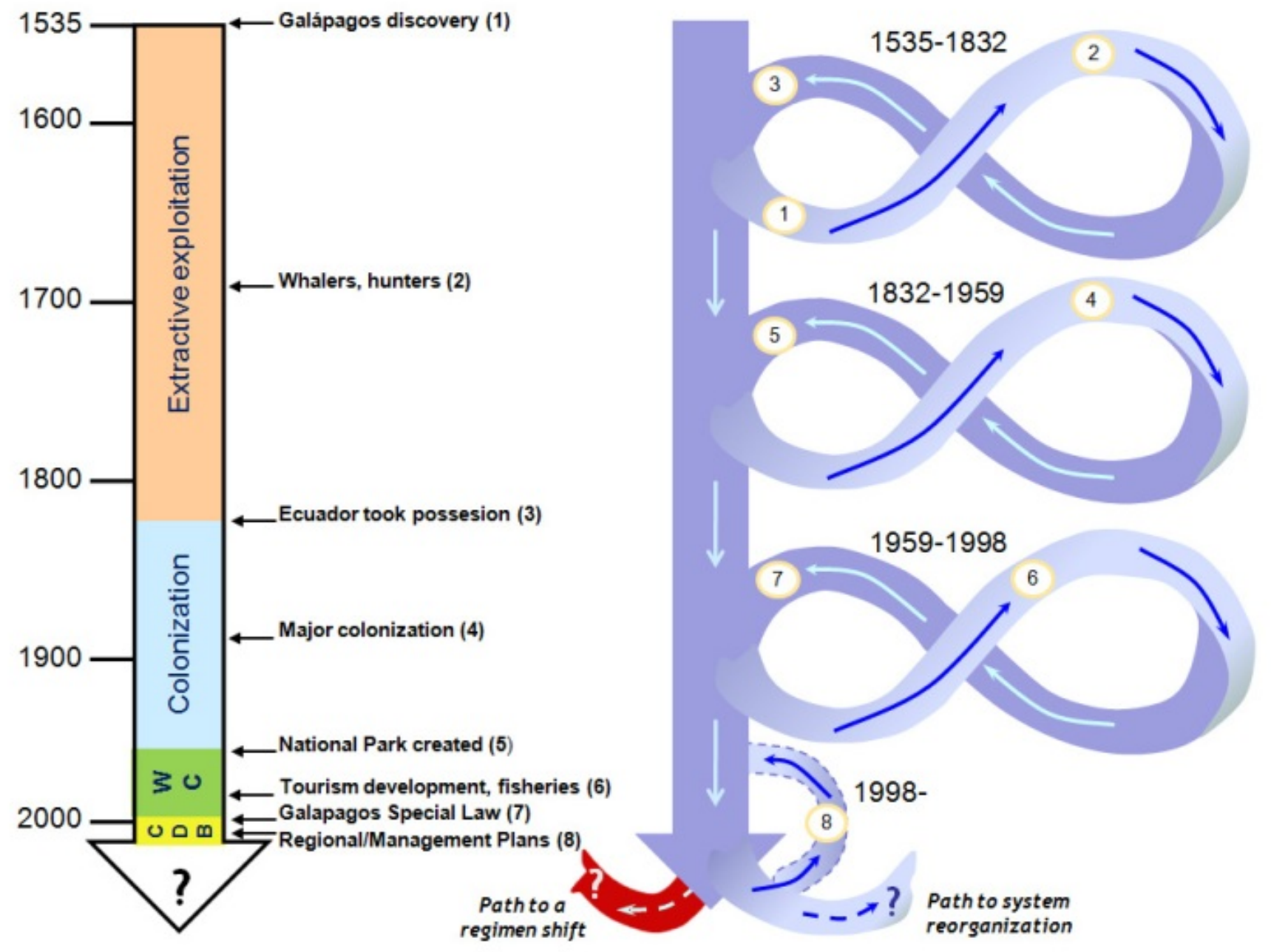

Historical periods and events

Adaptive cycles of renewal

The total human population of Galapagos increased from 1346 in 1950 to 18,640 in 2001 (Instituto Nacional de Estadística y Censos 2002). A 2006 census recorded 19,184 permanent residents (Instituto Nacional de Estadística y Censos and Instituto Nacional Galápagos unpublished report), but the total population of the islands probably exceeds 25,000 if temporary and illegal residents are included in the tally. Five islands are now host to permanent human settlements that range in size from $\sim 60$ inhabitants (Baltra) to $>9000$ inhabitants (Santa Cruz). Despite the wide range of restrictive measures provided by the Galapagos Special Law and recent efforts guided by local authorities, immigration from mainland Ecuador is still the major factor behind the high annual rates of population growth ( $5.9 \%$ between 1990 and 2001; Instituto Nacional de Estadística y Censos 2002). Using the maximum and minimum average growth rates recorded since 1950 , it is estimated that the 
local population will double sometime between 2017 and 2024. Population growth is mostly concentrated in coastal urban areas. The proportion of rural population in Galapagos decreased from $42 \%$ in 1974 to just $15 \%$ in 2001 (Instituto Nacional de Estadística y Censos 2002).

The growing human presence in the archipelago is coupled with the introduction of new alien species, either intentionally or accidentally (Fig. 3). The increasing array of invasive alien species has been recognized as the largest single threat to Galapagos biodiversity in the short term (Snell et al. 2002). Despite the significant efforts and resources that have been invested to improve the inspection and quarantine systems, a recent inventory of alien insects introduced to Galapagos recorded 463 species, 186 more than in the previous inventory in 1998 (Causton et al. 2006). Introduced plant species have also increased and now clearly outnumber the native flora (Magee et al. 2001, Tye et al. 2002). Snell et al. (2002) estimated that since 1535, the introduction rate of new species has been approximately 10,000 times the natural rate and has probably increased significantly in modern times.

Tourism is, by far, the most important driver of the Galapagos economy, employing almost $40 \%$ of local residents and contributing $65.4 \%$ of the archipelago's gross domestic product (Taylor et al. 2003). As the major economic activity, the current model of tourism is also the major driver of immigration and is therefore expected to play a determinant role in the future sustainability of the archipelago. Visitor numbers have grown steadily from $<12,000$ in 1979 to $>130,000$ in 2006 (Fig. $3)$. The combined capacity of vessel berths and hotel beds has also increased from 811 in 1982 to 3473 in 2006. The hotel lodging capacity rose by a factor of eight during the same period (Epler and Proaño 2007). This rapid increase is currently the main driver of change in the archipelago, as has been suggested previously (de Groot 1983, Grenier 2000, Taylor et al. 2003).

A corresponding growth of infrastructure and consumption has accompanied the population and tourist boom. Fuel consumption in the islands has increased at an average annual rate of $8.2 \%$ since 1997 and 9.5\% between 2003 and 2006 (Petrocomercial unpublished data). Also affecting growth is the subsidization of the Galapagos economy, which indirectly promotes excessive consumption of resources and services. State subsidies to the archipelago, including subsidies to energy, education, transport, water, and fuel, are estimated to total approximately US $\$ 15$ million annually (Kerr et al. 2004). Subsidies introduce important economic distortions that have indirect effects on migration patterns and create numerous environmental externalities. Excessive subsidization, by providing misleading and improperly directed incentives, can reduce the capacity of a system to self-organize (Anderies et al. 2006).

Agriculture and cattle ranching are also critical for conservation and sustainability because these activities occupy the most vulnerable ecosystems of the humid highlands. These areas are essential for alien species control and the maintenance of the natural hydrological regime. At present, a substantial portion of these lands is idle and no longer farmed (up to $43 \%$ on San Cristóbal Island). Because they are no longer actively managed for agricultural purposes, they have become centers of establishment and propagation of introduced species that easily invade neighboring properties, including the National Park. Moreover, reduced local agricultural production increases the bulk of fresh, perishable foods imported from the mainland, which are the main vector of new invasive species arrival (Cremers 2002). Finally, of special concern is the fact that many of the rural lands that were formerly used for agricultural purposes are now being developed for residential housing (Kerr et al. 2004).

The exploitation of natural resources in Galapagos has been, to a large degree, unplanned. As such, some of these resources have been degraded to a point where their future viability is in question. The overexploitation of coastal fisheries is the most apparent example, but the uncontrolled removal of building materials such as sand, rock, and timber for use in housing, road construction, and other activities can also cause adverse environmental impacts. Illegal fishing (mostly for shark fins), the illegal extraction of native and endemic species, the lack of wastewater treatment, groundwater pollution, and improper waste management practices are other issues that must be addressed in the near future.

Correlated with these environmental problems is the current social and institutional instability. Social conflicts associated with resource use and management decisions increased during the last decade. Fishermen riots, often with episodes of 
Fig. 3. Recent evolution of several direct and indirect drivers of change in the Galapagos socialecological system. GNP, Galapagos National Park; INGALA, Instituto Nacional Galápagos or Galapagos National Institute.

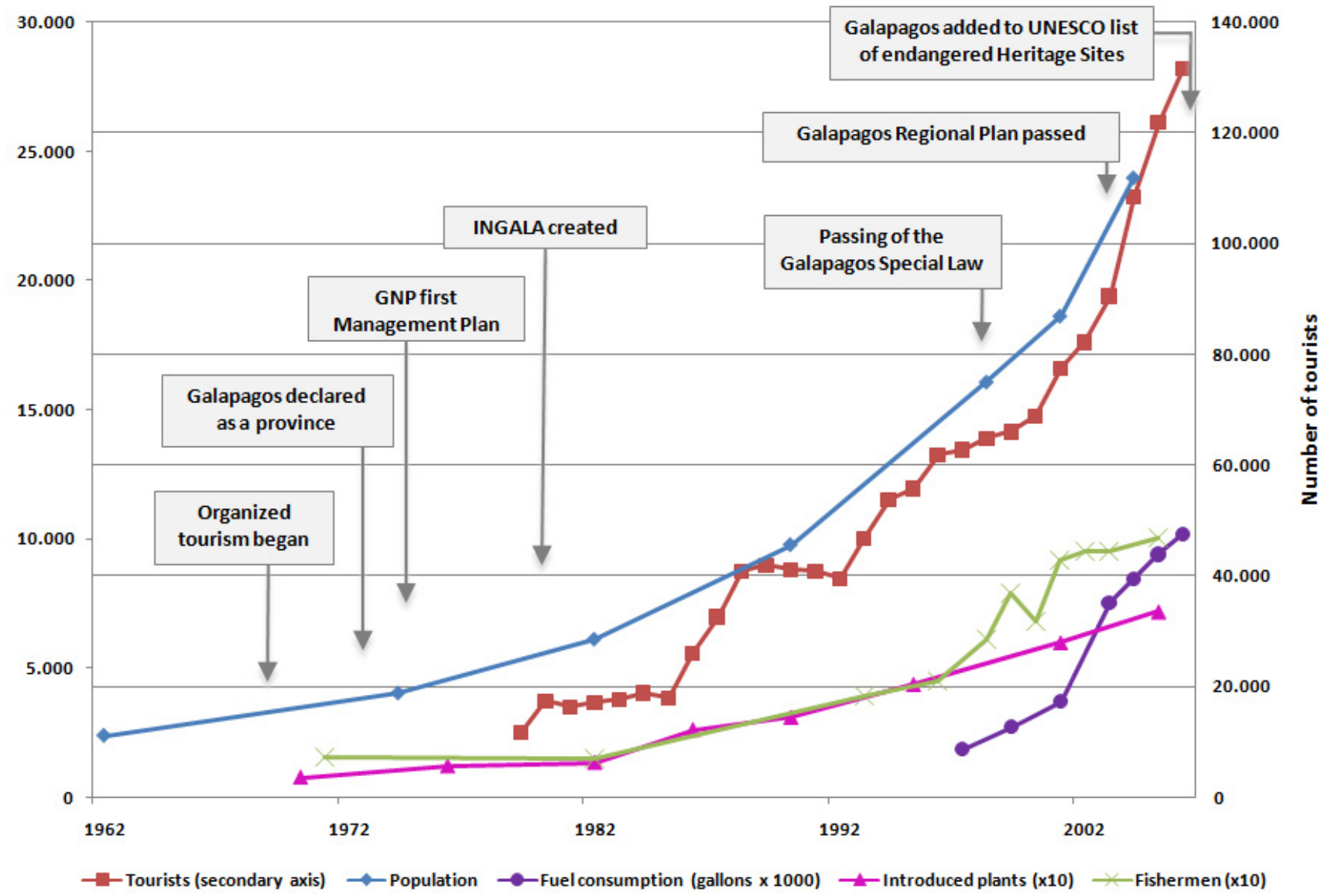

violence, increased from 6 days in 2000 to 11 days in 2002 and 14 days in 2004 (Ospina and Barber unpublished report). A March 2007 struggle between park rangers and army officers, resulting in the hospitalization of four rangers, clearly reflects the high degree of tension among institutions. Another indicator of institutional weakness is that the overall public image of the four major institutions governing the islands, inferred from social opinion enquiries, has declined sharply since 1999 (Barber and Ospina 2007).

Funding is frequently mentioned as a limiting factor for sustainability in Galapagos. However, the numbers suggest that funds invested in conservation and sustainable development initiatives have increased notably during the last decade (González 2007). The budget of Galapagos National Park rose from US\$4.5 million in 1999 to US\$9.2 million in 2006. External funding provided by bilateral and multilateral international agencies increased from approximately US\$2.5 million in 1999 to > US\$11 million in 2005. A recent United Nations Development Program inventory recorded at least 69 projects financed by international donors that were implemented in Galapagos between 1998 and 2005 , with an overall investment of US\$64 million (Oleas unpublished report). These data suggest that the allocation of additional money, although probably necessary considering the magnitude of the problems, is not by itself a solution to the crisis faced by the archipelago. 
Underlying all of this is a weak and unstable governance system at many levels, associated with instability in the leadership of major public institutions. For example the Galapagos National Park Service has had 11 different directors since 2002. Progress is hampered by frequent political interference in technical decisions, lack of trust among stakeholders, incipient and nonintegrative regional planning processes, and the absence of a broad vision for the future.

\section{WHERE ARE WE GOING? PLAUSIBLE FUTURE SCENARIOS}

Based on the integrative analysis of Galapagos' social-ecological problems, we modeled three different plausible scenarios (Fig. 4) that were discussed in participatory workshops with local stakeholders. The endogenous model (safe-keeping of natural capital; Fig. 4A) revolves around a natural capital that is composed of healthy insular and marine ecosystems and generates a rich and varied flow of ecosystem services. The most important of these services is the provisioning of high-value pristine spaces and unique biodiversity that encourages high-quality, low-impact nature tourism. In this model, the money generated by tourism is then invested to improve the well-being of local residents and to restore and maintain the natural capital on which societal welfare depends. There was agreement among stakeholders that this endogenous model, if achieved, would be selfsustaining and is the most desirable state for the archipelago. The model was adopted in the recent Galapagos National Park Management Plan (Parque Nacional Galápagos 2006) as the future target on which management actions should be focused.

However, the current situation of the archipelago can be better described as a continentalized or exogenous model (consumption and stocking; Fig. 4B), which is poorly adjusted to the fragility, uniqueness, and particularities of the archipelago. In this scenario, human links to mainland Ecuador are strong and increase with time. Galapagos imports labor and supplies from the continent and exports conservation and wealth to Ecuador and the rest of the world through tourism and science. In this sense, the archipelago is functioning as an open system that is highly dependent upon the continent and influenced by external political and commercial interests.
Some major social effects of this model are high immigration rates, dependence on extra-insular goods and services, the need for subsidies and external financial support, and the predominance of curative (reactive) policies rather than preventive (proactive) ones. Ecological effects can be summarized as a rapid loss of natural capital through an increased number of invasive species, overexploitation of fisheries, misuse of scarce resources, groundwater pollution, and overall degradation of native ecosystems.

The current dominance of the exogenous model is determined, to a large degree, by the choices of local residents who select a short-term economic growth pattern in which there are few limits to the use of ecosystem services and most of the subsequent benefits are invested in obtaining consumer and material goods. As a result, the local overheated economy continues to attract people from mainland Ecuador in search of employment opportunities and economic advantages. The growing population increases the demand for continental resources and more consumer goods, which reinforces external dependence in a positive feedback loop. Natural capital degrades with each new loop, losing its capacity to self-organize and generate ecosystem services for human welfare. This model can only be sustained through significant and continuous external input of human, financial, and material resources.

Finally, a third possible scenario was identified in which, after several loops of degradation, natural capital reaches a point at which it can no longer supply the high-quality sites needed for nature tourism (perverse model; Fig. 4C). In this event, the only tourism model will be one of massive recreation, a situation in which Galapagos could hardly compete with other global locations. In the perverse model, the Galapagos landscape would probably end up looking like other oceanic archipelagos that were colonized much earlier, where native biodiversity and ecosystems have been sharply transformed by human occupation and the proliferation of alien species, e.g., Hawaii, Canary Islands. Fortunately, this scenario was perceived as undesirable by most of the local, national, and international stakeholders. Nevertheless, the possibility of realizing this future situation is quite real if current development trends continue.

The shift from one regime to another might well be determined by the system's resilience, interpreted 
Fig. 4. Simplified modeling of three plausible interconnected scenarios for the Galapagos socialecological system, showing the tourism model as the main indirect driver of change.

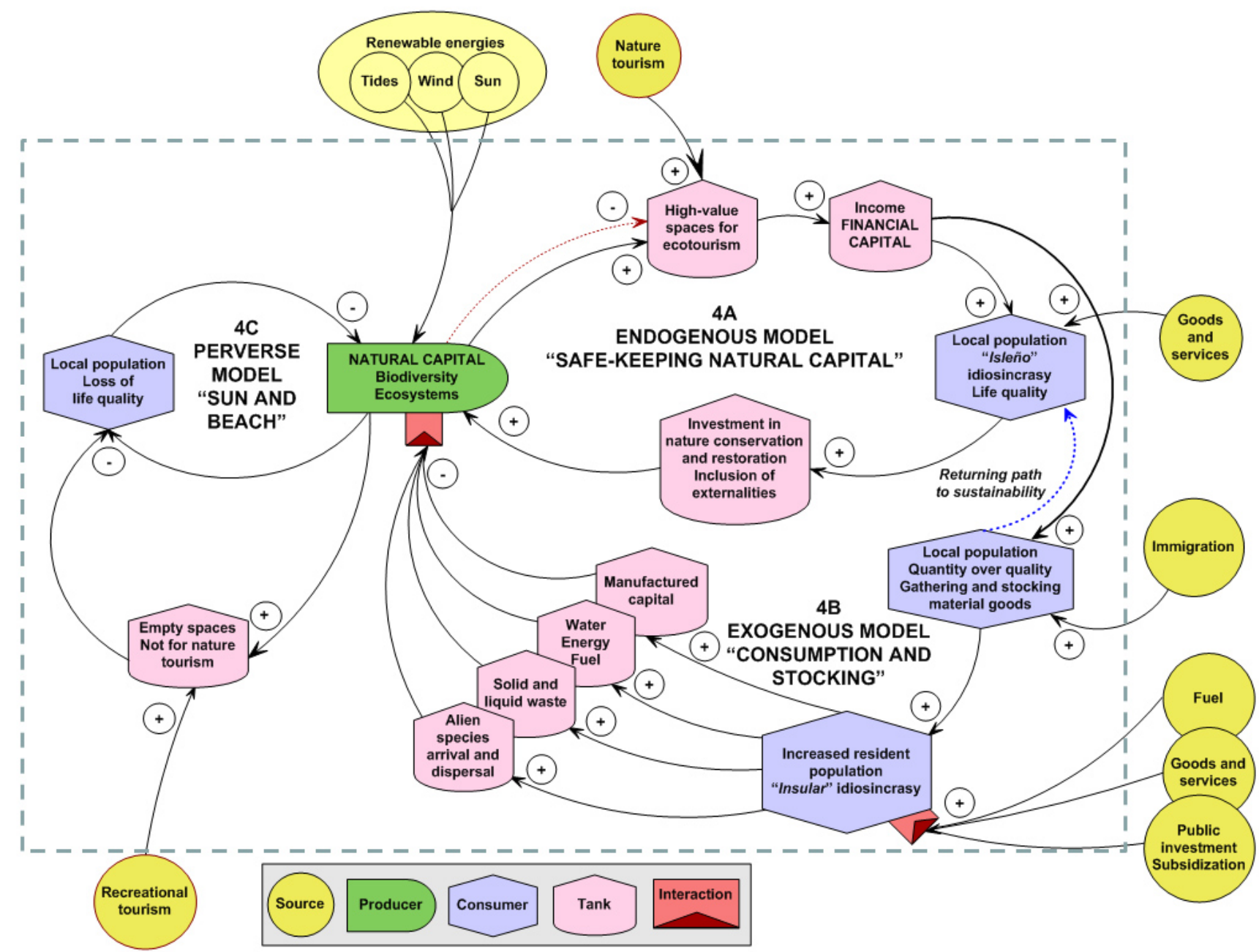

as the capacity of the system to experience shocks while retaining essentially the same function, structure, feedbacks, and therefore identity (Walker et al. 2006). Under this framework, the endogenous model would represent the most resilient and least vulnerable state. The current exogenous model can be characterized as a transitional situation, the course of which could be favorably altered if proper decisions are made. In contrast, failure to address the negative aspects of the current model could lead to a less desirable state; when the tipping point or threshold is crossed and social-ecological resilience is significantly eroded, then damage becomes irreversible (Fig. 5).

In all three models, tourism acts as the primary indirect driver of change through its direct effects on other drivers like population growth (mostly from illegal immigration), movement of goods and services, and resource consumption. Economic opportunities derived from tourism development also have the potential to influence other economic sectors such as fishing, agriculture, and commerce. The increasing array of exotic species and the 
Fig. 5. Interpretation of the three scenarios in terms of their resilience and vulnerability to unpredictable disturbances. See Table 2 for a detailed explanation of the differences between insular and isleño lifestyles.

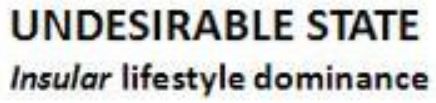

UNDESIRABLE STATE

DESIRABLE STATE

Isleño lifestyle dominance
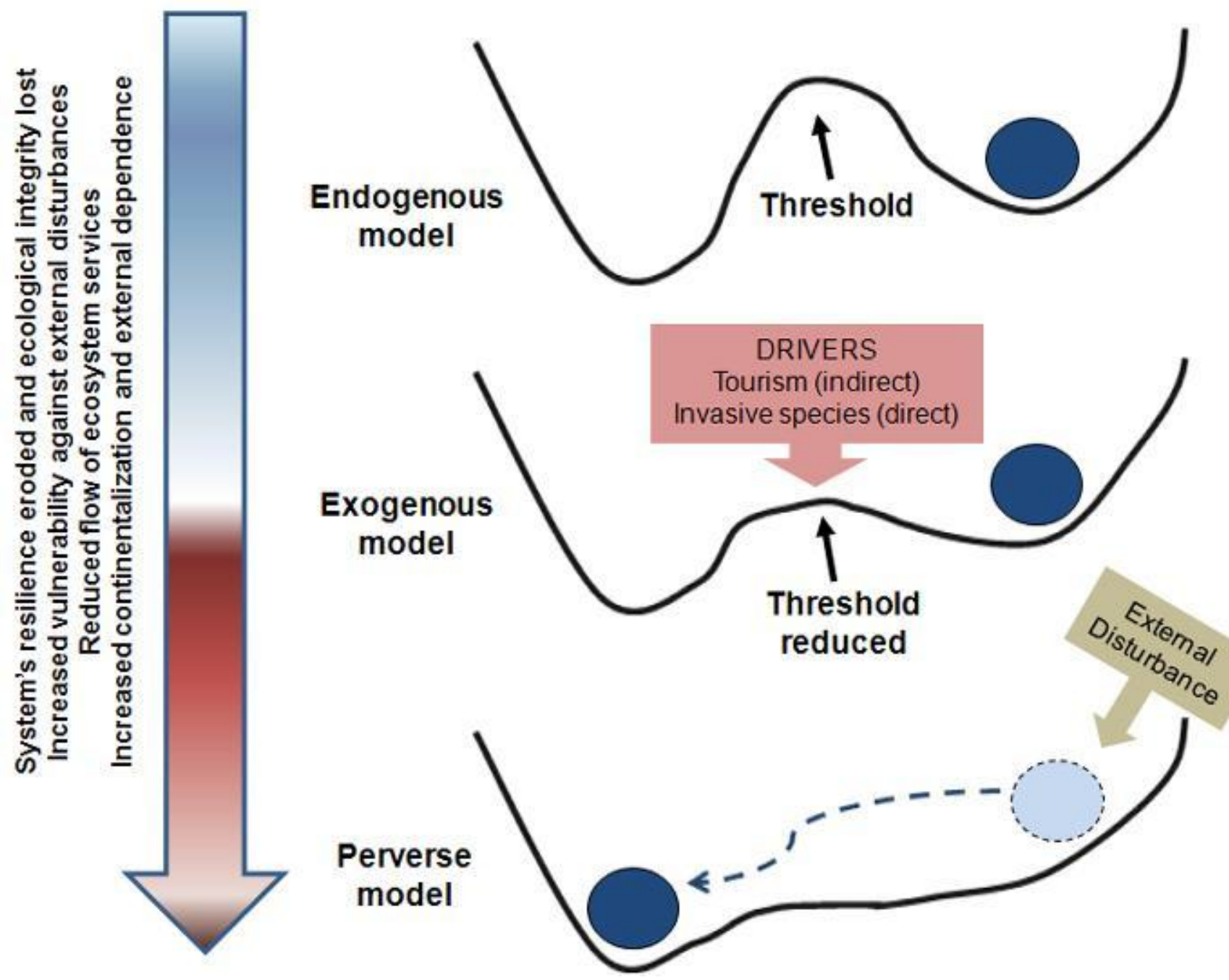

associated loss of natural capital are also indirect consequences of ongoing development of the tourism industry.

Positive feedback associated with tourism development creates additional demands that are beyond the social and environmental capacity of the islands (Kerr 2005). In Bonaire, in the Netherlands Antilles, new energy flows associated with ecotourism development have been identified as a major driver behind the transformations of the ecology and sociocultural system, moving the island toward a new state (Abel 2003). This pattern is quite similar to the current Galapagos situation. 
Therefore, the widely promoted model of locally based tourism should be carefully planned with identifiable limits (Grenier 2000, Kerr et al. 2004). Although it has the potential to be highly beneficial, some controls must be placed to ensure the conservation of the archipelago's natural ecosystems and to avoid a shift to a socially and environmentally undesirable state.

A return to the self-sustaining endogenous model may be difficult given the present situation. It is, however, not inconceivable that such a shift could occur, relying largely on a new generation of galapagueños (Galapagos people) who have a different attitude toward the environment. These individuals must be willing to adopt a new lifestyle that is adjusted to the carrying capacity of the islands, only slightly dependent on continental resources, and highly conscious of the fragility and limits imposed by living in an oceanic archipelago. Unfortunately, the curriculum of the Galapagos educational system lacks the necessary elements to instill an understanding of the unique and fragile nature of the islands and create a sense of living in a special place.

The dialectic between insulares and isleños (Table 2 ) is consistent with the scenarios described above and has been the focus of some of the most influential social and anthropological research conducted in the archipelago (Rodríguez 1993, Grenier 2000, Ospina 2001). Insulares are people from the continent that move to the island in search of social and economic advantages. This pattern fits most of the present Galapagos inhabitants, who brought from mainland Ecuador their way of life, cultural traditions, and exogenous productive and extractive patterns. In contrast, isleños are people whose idiosyncrasy is deep-rooted in the island territory, although not necessarily born there, and who have developed their own cultural practices, traditions, and productive patterns. The isleño lifestyle assumes that living on the Galapagos Islands is notably different from living on the continent and requires the acceptance of limitations and restrictions associated with the islands' fragile natural systems (Rodríguez 1993).

Cultural identity, sense of place, and relationship to the proximal environment have been identified as emergent properties of social-ecological systems (SESs) that are essential for building resilience and ensuring sustainability (Davidson-Hunt and Berkes 2003). Taking into account the recent colonization of the archipelago and the mixed geographical origin of the colonists (Kerr et al. 2004), the process of constructing such identities in Galapagos is still in a very early stage. Grenier (2000) proposed that the cultural identity of galapagueños is mostly characterized by an absence of identity, as might be expected in such a young SES. However, the appearance of a sense of distinctiveness from foreigners and continental people and an increasing consciousness of community may signal the birth of a cultural identity that could be rapidly emerging in Galapagos (Ospina 2001). If this new identity could be coupled with the adoption of an isleño lifestyle (Table 2), it might be the key to building social-ecological resilience and initiating the transition toward a more sustainable archipelago.

\section{GALAPAGOS AS A SPECIAL SOCIAL- ECOLOGICAL SYSTEM}

A social-ecological system (SES) can be defined as an ecological system that is intricately linked with and affected by one or more social systems (Anderies et al. 2004). This concept emphasizes the "humans-in-nature" perspective (Berkes and Folke 1998). Given this description, Galapagos can be correctly characterized as an SES. The natural and socioeconomic systems in the archipelago share many characteristics and are linked by dynamic processes and reciprocal feedback mechanisms, with a substantial exchange of energy and materials across boundaries. These links have been, and will continue to be, major determinants of the archipelago's situation. Economic activities, including tourism, artisanal fishing, and agriculture, completely depend on the integrity of native ecosystems and the services that they provide. Conversely, the future conservation of the unique biodiversity and ecosystems of Galapagos will largely depend on local residents, who must ultimately assume the responsibility for maintaining positive economic and social practices.

Galapagos exhibits most of the characteristics of complex human-nature adaptive systems such as feedbacks, nonlinear relations and thresholds, cross-scale interactions, regime shifts, and uncertainty (Levin 1998, Cundill et al. 2005, Liu et al. 2007). Reciprocal interactions and feedback loops are quite evident. For example, the conditions of ecosystems affect nature tourism, which is the major economic activity on the islands, whereas economic development associated with the tourism 
Table 2. Some differences between the "insular" and "isleño" lifestyles, as determinants of future sustainability patterns in the archipelago.

- Reject limitations and aspire to have the same level of services and reproduce the same consumption patterns in Galapagos as do people on the continent

- Live on the island, but have an ethnic origin from the continent or other external geographic area

- Traditions and cultural expressions deeply rooted to the place of origin, favoring external cultural models

- Colonist mentality, with strong links to continental relatives

- Maintain the same food preferences as in the place of origin, importing mainland products that are not present in the islands

- Replicate the same productive and extractive practices as in the place of origin

- Natural resources management disconnected from the island environment

- Create demand for externally derived goods, increasing dependence on noninsular resources

- Low identification with the island territory; permanent feeling of just being in transit
- Accept that Galapagos is a special place where some limitations are necessary and where living requires a different consumption pattern from that on the continent

- Have lived on the island for a long period of time, although not necessarily born there, ensuring an intergenerational connection

- Cultural traditions developed locally or brought from the place of origin but incorporating elements of the island reality

- $\quad$ Resident mentality, with a marked sense of place

- Food preferences adapted to the island reality and resource availability

- Adopt new productive patterns consistent with the biophysical and environmental constraints of the archipelago

- Natural resources management deeply rooted to the territory

- Create supply and mobilize local resources, building alliances and interdependence

- Identity and sense of place highly developed; intergenerational permanence guaranteed 
- Preference for projects designed outside of the islands

- Reproduce the same building patterns as in the place of origin

- Promote competition among islands of the archipelago

- Low rate of participation in the monitoring, planning, and decision-making processes
- Create the capacity to locally design and implement projects

- Develop a construction style based on the use of local materials

- $\quad$ Promote collaboration and solidarity among the islands of the archipelago, avoiding excessive competition

- Highly participative and concerned about the planning and decision-making processes industry often degrades the quality of some of the islands features that attract tourists. Nonlinearity and thresholds are also characteristic of many processes in Galapagos. The uncontrolled extraction of fresh groundwater, for example, may lead to the infiltration of seawater, eventually making the aquifer unusable. Urban development and buildup on former agricultural land is likely to result in the loss of native humid forests, which could have serious ecological consequences. In both of these cases the natural buffers are only effective up to a certain transition point or threshold. Exceedance of the threshold will push the process or system into a new, alternate state. Cross-scale interactions also occur in Galapagos, taking into account the total dependence of the islands on external markets that are influenced by larger-scale processes. Finally, Galapagos is particularly susceptible to sudden and potentially catastrophic impacts such as the arrival of an invasive species or exotic disease, an El Niño event, or dramatic political or legal changes. Such vulnerability contributes to the uncertainty that overshadows the archipelago, making predictions of future conditions even harder.

The impacts of prior human-nature couplings (legacy effects) are also present everywhere in the Galapagos SES. For example, the forest conditions on the highlands of the inhabited islands have been shaped by the colonization processes that took place almost two centuries ago. The historical introduction of goats on several islands is still limiting efforts to preserve emblematic species such as the giant tortoise. Moreover, the ecological and socioeconomic impacts of human-nature couplings may not be apparent immediately because of time lags (Liu et al. 2007).

However, despite the current and historical examples of human-nature interactions, it appears that Galapagos cannot be conceptualized as a typical example of the humans-in-nature paradigm that characterizes most SESs (Davidson-Hunt and Berkes 2003, Carpenter and Folke 2006). In contrast to continental areas and other oceanic archipelagos, which are mostly human-dominated, the vast majority of the land in Galapagos is strictly preserved as a National Park, which excludes direct human use. The historical isolation of the archipelago, the absence of an aboriginal population, and the relatively recent human colonization precluded the coevolution of cultural and natural forces. In Galapagos, unlike in other SESs, ecological and evolutionary processes are still minimally affected by human activities, a situation that should be maintained. In view of the uniqueness of the Galapagos case, we think that the SES might be better described and analyzed under a "humans-with-nature" paradigm (Fig. 6) in which the island residents act as the guardians of the natural capital on which their present and future welfare relies. This is the innovative approach that was adopted in the recent Galapagos National Park Management Plan (Parque Nacional Galápagos 2006). 


\section{NEW APPROACHES TO OLD PROBLEMS}

Rethinking the Galapagos situation under the resilience perspective provides insights for improving current management practices and conservation policies. Although some of the ideas that we next detail and discuss can be considered as improved reformulations of proposals included in regional planning instruments such as the Galapagos Special Law (GSL), we think that others represent very innovative approaches to tackling the archipelago's current situation.

\section{Moving toward a "conservation for development" approach}

The fundamental division between conservationists and development advocates has traditionally been a matter of serious conflict in Galapagos (Grenier 2000). Breaking this nature vs. society dichotomy and building bridges between these two artificially separated worlds is essential if a broadly shared vision for the future of the archipelago is to be reached. The Millennium Ecosystem Assessment framework conceptualizes ecosystems as natural capital that, if properly managed throught restoration and conservation, will generate a rich flow of ecosystem services for socioeconomic development (e.g., pristine areas and unique biodiversity for nature tourism; Millennium Ecosystem Assessment 2005). The adoption of this framework would be highly appropriate in Galapagos as a means of reconciling the interests of various user groups and stakeholders at the local, national, and international levels.

As we have discussed, there is a clear need in Galapagos to abandon the historical perspective of the separation of humans from nature, which only exacerbates conflicts between conservation and development. In a place where people are highly dependent on the integrity of the natural system and where the economic development model shapes ecosystem dynamics, sustainability will only be reached through an integrative and inclusive process. In this sense, the old paradigm of equilibrium between conservation and development, which is used extensively by major public institutions, should probably be abandoned in favor of a "conservation for development" paradigm (sensu Folke 2006a) in which the conservation of natural capital is not an option, but a requirement, if a high quality of life for Galapagos residents is to be attained and sustained.

\section{Adopting a more integrative approach to territorial planning}

The GSL made it clear that the archipelago should be managed as a whole and unique geographic space, encompassing both the inhabited areas and the protected areas. This fundamental idea has been adopted in the Galapagos National Park (GNP) Management Plan, but has not yet been truly implemented.

Because the existing protected areas are unlikely to incorporate the long-term and large-scale dynamics of ecosystems, conservation strategies must include those areas that are managed primarily for human use. The ecological memory of Galapagos, for example, which is composed of the species, interactions, and structures that make ecosystem reorganization possible, is highly dependent on the occupied highlands, many of which show substantial perturbations. The native ecosystems of the humid highlands are spatially restricted, highly diverse, and particularly rich in endemic species. They are also essential for maintaining the hydrological regime and other key ecosystem processes. Historically, these areas have been the most attractive to human settlement because they have fresh water and rich volcanic soils for cultivation. On Santa Cruz and San Cristóbal, the islands with the largest rural populations, as much as $74 \%$ and $93 \%$, respectively, of the highlands have been transformed and occupied for agriculture (Snell et al. 2002).

There are also substantial and inseparable ecological links between terrestrial and marine ecosystems in Galapagos, in terms of both chemical cycles (e.g., nutrients) and energy fluxes. One of the downfalls of some land-based or sea-based conservation units is that they fail to consider the linkage between terrestrial and aquatic environments. Management plans for the GNP and the Galapagos Marine Reserve (GMR), as well as territorial planning for occupied areas, should be restructured toward a more comprehensive and holistic scheme. To accomplish this, ecoregion-based planning models or the Biosphere Reserves framework may be good approaches for developing a more integrative management strategy for the archipelago. 
Fig. 6. The "humans-with-nature" perspective, which is suggested as a way to bridge the conservationdevelopment divide in Galapagos, as compared to the typical "humans-in-nature" paradigm that characterizes most social-ecological systems.

\section{People-in-nature}

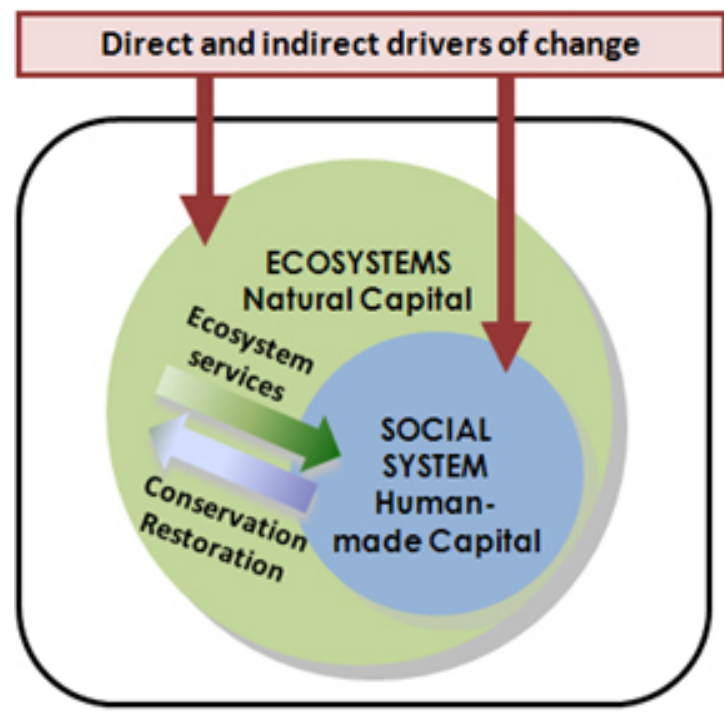

People-with-nature

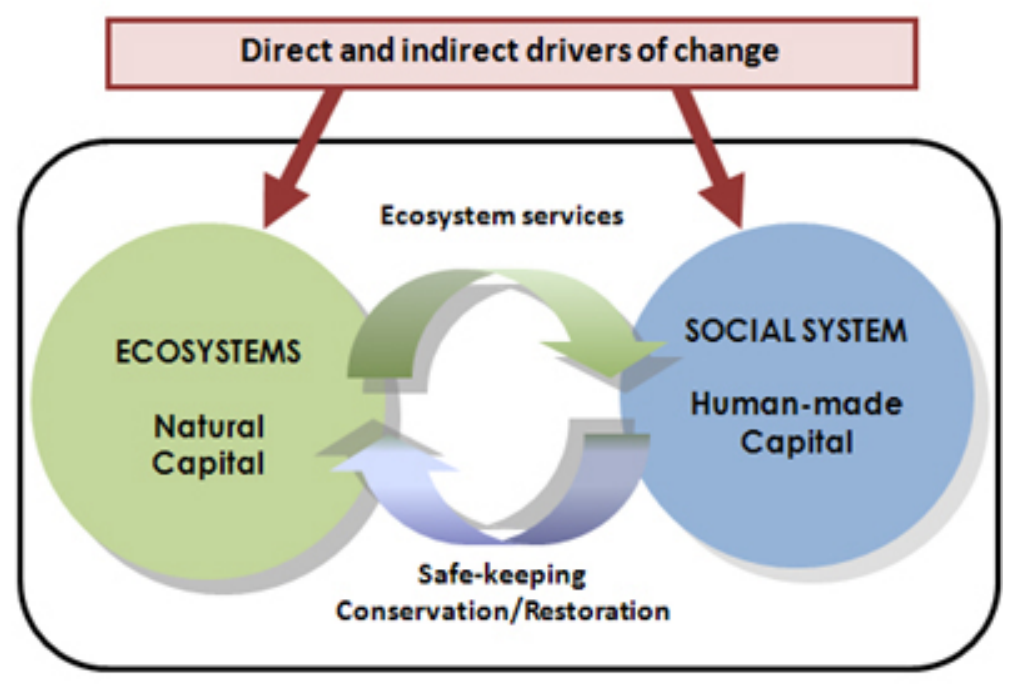

Some other elements that should be considered in a new, comprehensive territorial plan for Galapagos are: (1) the promotion of a "real archipelago" approach, with effective cooperation among the islands, including the sharing of public services and costs to increase efficiency; (2) the reorganization of the existing web of transportation between mainland Ecuador and the islands and among the islands, with the goal of reestablishing (as much as possible) the historical ecological barrier that has insulated the fragile island environment; (3) the avoidance of significant land-use modifications in the agricultural areas, including restrictions on residential development, because these areas are essential for maintaining ecological integrity; (4) the promotion of cooperation between the Galapagos National Park Service (GNPS) and landowners in the GNP buffer zones, e.g., through conservation easements or other similar agreements; and (5) the promotion of economic diversification to reduce dependence on tourism as an insurance policy against unexpected changes in the tourist market.

\section{Promoting a resilience-based management approach with emphasis on slowly changing variables and functional diversity}

The active management of resilience is required to sustain desired system states in the face of increasing environmental change and growing human pressure (Folke et al. 2004). In this sense, perturbations and crises should be perceived as opportunities to modify old management paradigms that diminish the system's adaptive capacity and its ability to cope with change and uncertainty. Efforts to reduce the risk of unwanted shifts should address the gradual changes that affect resilience, rather than merely controlling disturbance, which has been the traditional focus of management in Galapagos.

Resilience is highly dependent on slowly changing variables such as land use, nutrient stocks, hydrological regime, soil properties, and the abundance of long-lived organisms (Scheffer et al. 2001, Abel et al. 2006). However, the study and management of these types of variables have been nearly absent from Galapagos conservation 
policies, which have been narrowly directed toward the conservation of emblematic or threatened biota and the control of invasive organisms. An understanding of the slowly changing variables is critical to develop sound policies that manage for resilience (Carpenter and Turner 2000, Holling 2001). However, it is human nature to react to and focus on variables that change rapidly, represent a clearly visible alteration to the norm, or garner attention from the public, government, or other influential groups. In Galapagos, these quickly changing variables might include, for example, the arrival of new exotic species, the recognition of an endangered species, or a fishermen riot. However, issues with quickly changing variables may be only symptoms of a problem with longer-term dynamics that could have been prevented by managing for slowly changing variables. The failure to manage these slowly changing variables can lead to irreversible changes in the system (Chapin et al. 2004). Thus, promoting a resilience-based conservation approach in Galapagos will require the implementation of an active agenda to determine, investigate, and manage the key slowly changing variables in which the system's resilience resides.

The conservation of biodiversity is also essential as insurance to maintain resilient ecosystems and ensure a sustainable flow of ecosystem services (Bengtsson et al. 2003). In this sense, the preservation of native biota should remain a top priority in the archipelago, as it has been in the recent past. However, the current focus of research and management on the conservation of individual species and populations should be expanded to include other biodiversity components, particularly functional diversity, i.e., the type, range, and relative abundance of functional traits, because there is increasing evidence that it strongly determines ecosystem function (Díaz and Cabido 2001).

\section{Strengthening participative approaches and developing a shared vision}

Historical conservation policies that consider the human population as antagonistic to the environment should be abandoned. Taking into account the complexity of the environmental problems that Galapagos faces, working partnerships should be built between management agencies and resource users. Rather than supporting a hostile and counterproductive relationship, these partnerships would promote the participation and responsible sharing of multiple stakeholders from the initial stages of the planning process to the final decision making.

The participatory management system implemented in the GMR is a good example of a successful conservation practice that has been widely recognized (Baine et al. 2007, Heylings and Bravo 2007). Despite recurrent conflicts, great institutional progress has been achieved in fisheries and tourism management since the initial development of the multistakeholder process in 1998. The experience of the Participatory Management Board in moving from a top-down to a bottom-up management approach for the GMR clearly shows that social resilience can be successfully built through participation and cooperation among various stakeholders. Enhanced social and institutional resilience has allowed the system to remain functional despite several recent political and institutional crises (Heylings and Bravo 2007). Innovative ways of promoting resilience through participative management should also be explored for the whole archipelago by adapting the GMR framework to the specific peculiarities and goals of each area; for example, extractive uses are allowed in the GMR, but not in the GNP.

\section{Establishing strong institutional networks and promoting collaboration among stakeholders}

Although the existing number of interinstitutional committees in Galapagos is enormous, there are few examples of effective collaboration (Parque Nacional Galápagos 2006). Distrust among stakeholders and institutions has been identified as one of the most serious problems inhibiting effective governance in the archipelago (Ospina 2006). Breaking down and transforming entrenched philosophies and inherent suspicions can be one of the most challenging aspects of improving management strategies in Galapagos. However, such a transformation is urgently needed. The development of solid institutional networks and the promotion of joint activities will contribute to build trust among stakeholders and significantly improve the decision-making process.

This new management approach does not necessarily involve the creation of new institutions, but rather a reorganization within existing institutional frameworks, guided by a broadly 
shared vision and including the close coordination of activities. However, in establishing institutional networks, the creation of a new flexible organization might be necessary to initiate trust-building dialogue and mobilize actors across scales (Olsson et al. 2004).

\section{Implementing adaptive co-management models}

The conventional top-down "command-andcontrol" management practices that have prevailed for most of Galapagos' recent history should be set aside in favor of more adaptive co-management approaches. Adaptive co-management refers to the sharing of management power and responsibility through multiple institutional linkages involving both horizontal and vertical cross-scale interactions (e.g., government agencies, nongovernmental organizations, local communities, user groups) and to the building of mutual trust among the partners through feedback learning (Berkes 2004). Traditional command-and-control management practices are expected to reduce natural levels of variation and to solve a problem either through the control of the processes that lead to it or through the amelioration of the problem after it occurs. These practices are based on an inherent assumption that natural systems have an equilibrium state that has to be maintained or restored, seeking situations of minimum complexity and uncertainty. Under this approach, it is also assumed that the problems can be clearly defined and show linear cause-effect responses (Holling and Meffe 1996, Berkes 2004). Such command-and-control practices have been the usual approach to management in Galapagos, using the pre-1535 status of the archipelago as the benchmark and long-term goal for biodiversity conservation (Bensted-Smith 2002).

However, when these methods of strict control are applied to complex, nonlinear, and poorly understood social-ecological systems, as we have shown is the case in Galapagos, they usually result in unforeseen consequences for both natural ecosystems and human welfare. Unfortunate and undesirable results include collapsing resources, social and economic strife, and the loss of biological diversity, in what Holling and Meffe (1996) clearly described as the "pathology of natural resource management."

In the face of the growing human pressure that threatens the native biodiversity and ecological integrity of Galapagos, an adaptive co-management model is, undoubtedly, a better choice for the archipelago than conventional conservation frameworks based on increasing controls and regulations. In this sense, perturbation and change should be considered as an integral part of the functioning of the system because they allow for learning and renewal. The social-ecological monitoring schemes that are under implementation by the GNPS, the Charles Darwin Foundation (CDF), and other institutions offer a good baseline and would greatly facilitate such an adaptive (i.e., learning by doing) co-management approach.

\section{Favoring a new model of "science for Galapagos"}

The close link between science and management has always been one of the most positive aspects in Galapagos, as reflected in the long-term collaborative effort of the $\mathrm{CDF}$, which conducts research and provides advice, and the GNPS, which develops management actions and performs monitoring. However, a recent survey of 4884 published references indicated that research in Galapagos has been highly skewed toward basic biophysical sciences. Moreover, $<10 \%$ of the studies could be considered multidisciplinary, encompassing links among the natural, social, and economic systems (Santander et al. 2008). This highly biocentric focus has dominated research in Galapagos for decades, producing a thorough and valuable knowledge of some aspects of endangered and emblematic species. What remains, however, is a paucity of information on some social and ecological processes that are key components of sustainability: e.g., water and nutrient cycles, functional biodiversity, land-use changes, and environmental valuation.

Scientists, particularly those in the traditional biological and evolutionary fields, have always been attracted to Galapagos both for its unique ecosystems and, quite simply, its fame. In the absence of a long-term scientific plan, scientists' preferences for research topics have usually prevailed over more critical informational needs. To implement the adaptive resilience-based comanagement approach that we have outlined, a different model of sound integrative science for sustainability is necessary. A new agenda of research priorities should be established that is well beyond the personal interests of researchers or 
institutions (i.e., the present model of "science in Galapagos"), favoring investment in investigations that are directed toward solving the most urgent management and conservation problems (i.e., a new model of "science for Galapagos").

Solutions to the present crisis will also require a fusion of biological and social considerations. It is essential to increase the volume of research conducted at the frontiers of social and biophysical sciences (Scoones 1999, Berkes 2004). Such studies are critical because it is in the interactions between the cultural and natural worlds where most of the present and future problems of the archipelago reside. Complex problems like those outlined here, whose causes are multiple, diverse, and dispersed, cannot be understood through scientific activity organized along traditional disciplinary lines (Jasanoff et al. 1997). Much more emphasis should be placed on transdisciplinary research and integrative approaches framed in sustainability science (Kates et al. 2001), with emergent disciplines like political ecology, ecological economics, ecological anthropology, environmental ethics, and education for sustainability being promoted to provide the data needed to confront the present crisis and develop a more resilient archipelago that can endure the challenges of the future.

\section{CONCLUSIONS: CRISIS AS A RENEWAL OPPORTUNITY}

Despite limitations, the view of Galapagos as a social-ecological system (SES) from the resilience perspective has proven to be a useful tool to gain an understanding of the dynamics and overall functioning of the archipelago, as well as to identify the primary historical and current drivers of change. We think that this new perspective might also serve as a framework to bridge the human-nature divide whereby the more development-oriented positions can find common ground with the more conservation-based approaches and the social and biophysical sciences can identify mutually beneficial study subjects and methodologies.

Galapagos is at a critical period in its history. Reconciling the economic aspirations of a growing population with the conservation of the ecological integrity of the archipelago will not be easy. However, we think that the opportunity exists to develop Galapagos in a sustainable way. Achieving this goal will require the rapid adoption of strong political and management decisions to address the current risks to the system and forestall an eventual shift to a socially and environmentally undesirable regime.

Our resilience-based approach to the Galapagos situation reveals that tourism is, and will probably continue to be, the most important driver of change through its direct effects on the archipelago's ecology, economy, and socio-cultural system. Energy flows, growing economic opportunities, and positive economic feedback associated with the current model of tourism have the potential to accelerate major changes and threaten the sustainability of the archipelago in the near future. In its first stages, the model of cruise-boat tourism appeared to be a good choice for Galapagos, but after the rapid generalization of locally based tourism and the increasing presence of infrastructure and land-based services such as hotels, restaurants, and transportation, the economic growth driven by tourism became somewhat of a double-edged sword. On the one hand, it contributes to environmental conservation and improvements in the standard of living through taxes and admission fees; on the other hand, it overheats the islands' economy, creating new economic niches and opportunities that drive immigration and unsustainable growth. If the present crisis is to be solved, the identification of the most appropriate tourism model for Galapagos should be a top priority of research and planning for the next few years.

The current crisis can be perceived as a window of opportunity for the Galapagos SES to reorganize into a self-sustaining development model, but strong political and management decisions are urgently needed. Some of the key measures that should be adopted to position the system on a course of sustainable development are: modifying some of the traditional practices to embrace a more adaptive resilience-based co-management scheme, adopting a more comprehensive approach to territorial planning, strengthening participative approaches and institutional networks, and promoting transdisciplinary research. However, regardless of the approaches proposed here or the policies and management practices that are actually adopted, we think that it is the idiosyncrasy and way of life selected by the Galapagos residents that will determine the future of the archipelago (Fig. 7). The adoption of exogenous mainland-influenced 
Fig. 7. Idealized representations of two possible futures for Galapagos, which rely heavily on the lifestyle of the island residents: endogenous (left) vs. exogenous (right) development models. Reproduced with permission from Parque Nacional Galápagos (2007).

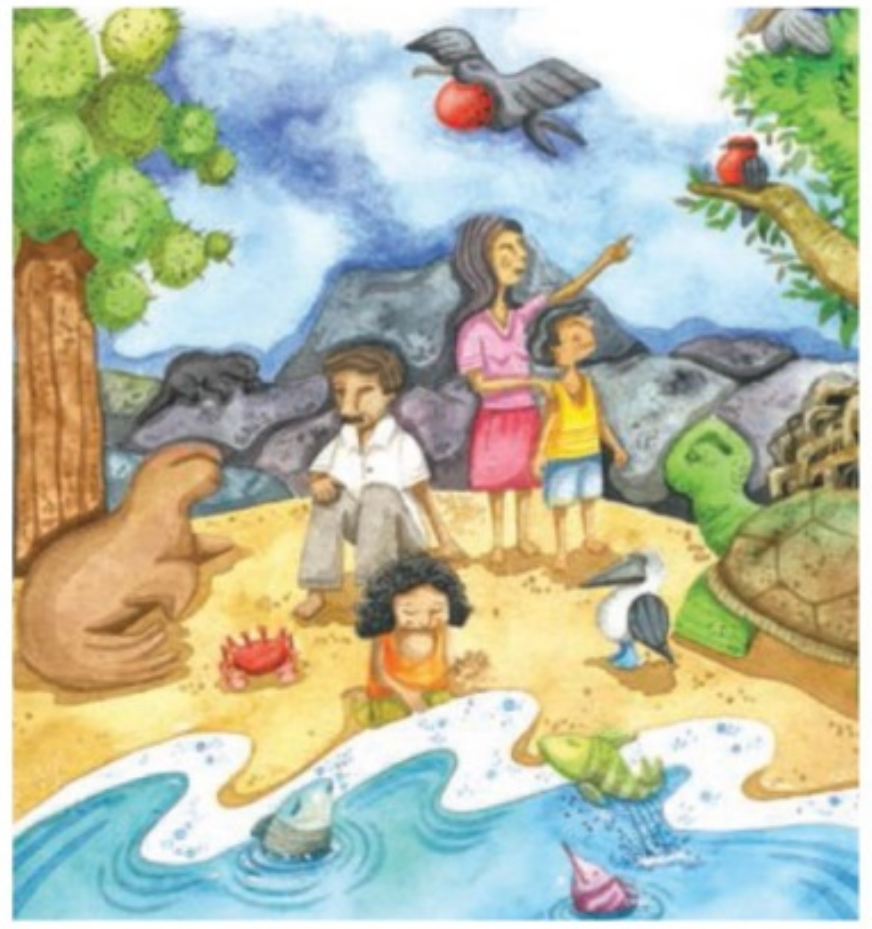

lifestyles will certainly continue to erode the system's resilience and hinder future sustainability. In contrast, more endogenous development models based on a particular lifestyle that assumes that living in Galapagos is fundamentally different and accepts the limitations associated with the archipelago's fragile natural system are the best and only way to facilitate the transition toward a more sustainable future.

Responses to this article can be read online at: http://www.ecologyandsociety.org/vol13/iss2/art13/responses/

\section{Acknowledgments:}

Most of the concepts and insights presented here are the result of a comprehensive, collaborative effort led by the Galapagos National Park Service

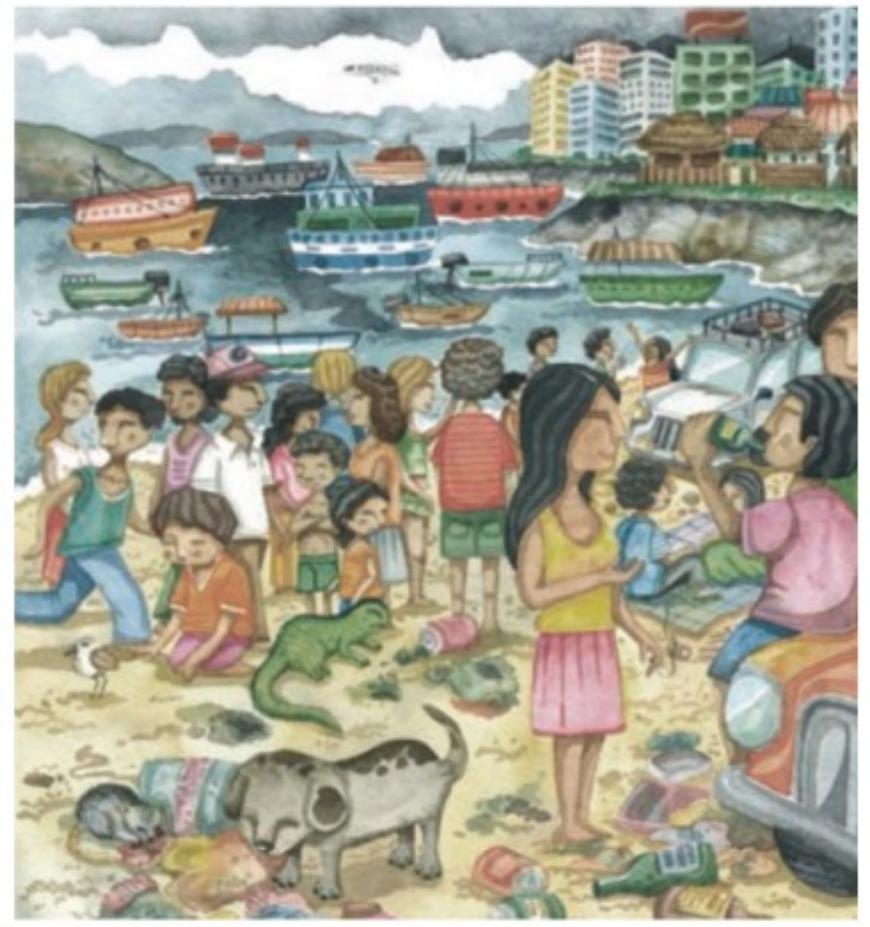

(GNPS), with technical assistance from the authors during 2004 and 2005, to review and update the management plan of Galapagos National Park. We gratefully acknowledge the GNPS staff, especially Mario Piu, Sixto Naranjo, Danny Rueda, Marco Hoyos, Edgar Muñoz, Edwin Naula, and Eliécer Cruz, who actively participated in the design of the new management framework for the protected area. We also thank Guido Mosquera for his continuous support and advice during the planning and development of the participatory process. The insights and critical comments of Howard Snell, José Villa, and Carlos Carrión were essential for the construction of the models and proposals outlined in this paper. We are also very grateful to the Galapagos National Institute (INGALA), the Consortium of Galapagos Municipalities, and the Charles Darwin Foundation, which provided logistic support and technical assistance during the whole process. Financial support for this work was provided by the Araucaria-Galápagos Program, a 
research grant from the Latin American Studies Center-Santander Group (CEAL-UAM), and the PCI Program for Latin America of the Spanish Agency for International Cooperation (AECI).

\section{LITERATURE CITED}

\begin{abstract}
Abel, N., D. H. M. Cumming, and J. M. Anderies. 2006. Collapse and reorganization in socialecological systems: questions, some ideas, and policy implications. Ecology and Society 11(1): 17. [online] URL: http://www.ecologyandsociety.org/vol11/ iss1/art17/.
\end{abstract}

Abel, T. 2003. Understanding complex human ecosystems: the case of ecotourism in Bonaire. Conservation Ecology 7(3): 10. [online] URL: http ://www.consecol.org/vol7/iss3/art10/.

Anderies, J. M., M. A. Janssen, and E. Ostrom. 2004. A framework to analyze the robustness of social-ecological systems from an institutional perspective. Ecology and Society 9(1): 18. [online] URL: http://www.ecologyandsociety.org/vol9/iss1/ art18/.

Anderies, J. M., B. H. Walker, and A. P. Kinzig. 2006. Fifteen weddings and a funeral: case studies and resilience-based management. Pages 163-176 in B. H. Walker, J. M. Anderies, A. P. Kinzig, and P. D. Ryan, editors. Exploring resilience in socialecological systems: comparative studies and theory development. CSIRO Publishing, Collingwood, Australia.

Baine, M., M. Howard, S. Kerr, G. Edgar, and V. Toral. 2007. Coastal and marine resource management in the Galapagos Islands and the Archipelago of San Andres: issues, problems and opportunities. Ocean and Coastal Management 50 (3-4):148-173.

Barber, H., and P. Ospina. 2007. Opinión de la comunidad isleña acerca del desempeño de las instituciones. Pages 94-97 in S. Cárdenas, coordinator. Informe Galápagos 2006-2007. FCD, PNG, and INGALA, Puerto Ayora, Ecuador.

Bengtsson, J., P. Angelstam, T. Elmqvist, U. Emauelsson, C. Folke, M. Ihse, F. Moberg, and M. Nyström. 2003. Reserves, resilience and dynamic landscapes. Ambio 32(6):389-396.
Bensted-Smith, R., editor. 2002. A biodiversity vision for the Galapagos Islands. Charles Darwin Foundation and World Wildlife Fund, Puerto Ayora, Ecuador. Available online at: www.darwinf oundation.org/files/library/pdf/bio vision galapagos eng. pdf.

Berkes, F. 2004. Rethinking community-based conservation. Conservation Biology 18(3):621-630.

Berkes, F., J. Colding, and C. Folke, editors. 2003. Navigating social-ecological systems: building resilience for complexity and change. Cambridge University Press, Cambridge, UK.

Berkes, F., and C. Folke, editors. 1998. Linking social and ecological systems: management practices and social mechanisms for building resilience. Cambridge University Press, Cambridge, UK.

Brand, F. S., and K. Jax. 2007. Focusing the meaning(s) of resilience: resilience as a descriptive concept and a boundary object. Ecology and Society 12(1): 23. [online] URL: http://www.ecologyandso ciety.org/vol12/iss1/art23/.

Bremner, J., and J. Perez. 2002. A case study of human migration and the sea cucumber crisis in the Galapagos Islands. Ambio 31(4):306-310.

Carpenter, S. R., and C. Folke. 2006. Ecology for transformation. Trends in Ecology and Evolution 21 (6):309-315.

Carpenter, S. R., and M. G. Turner. 2000. Hares and tortoises: interactions of fast and slow variables in ecosystems. Ecosystems 3(6):495-497.

Carpenter, S., B. Walker, J. M. Anderies, and N. Abel. 2001. From metaphor to measurement: resilience of what to what? Ecosystems 4 (8):765-781.

Causton, C. E., S. B. Peck, B. J. Sinclair, L. Roque-Albelo, C. J. Hodgson, and B. Landry. 2006. Alien insects: threats and implications for conservation of Galápagos Islands. Annals of the Entomological Society of America 99(1):121-143.

Chapin III, F. S., G. Peterson, F. Berkes, T. V. Callaghan, P. Angelstam, M. Apps, C. Beier, Y. Bergeron, A.-S. Crépin, K. Danell, T. Elmqvist, C. Folke, B. Forbes, N. Fresco, G. Juday, J. 
Niemelä, A. Shvidenko, and G. Whiteman. 2004. Resilience and vulnerability of northern regions to social and environmental change. Ambio 33 (6):344-349.

Costanza, R., L. Wainger, C. Folke, and K.-G. Mäler. 1993. Modeling complex ecological economic systems: toward an evolutionary, dynamic understanding of people and nature. BioScience 43(8):545-555.

Cremers, L. C. 2002. Irrigated agriculture on the Galapagos Islands: fit for survival. Thesis. Wageningen University, Wageningen, The Netherlands.

Cundill, G. N. R., C. Fabricius, and N. Marti. 2005. Foghorns to the future: using knowledge and transdisciplinarity to navigate complex systems. Ecology and Society 10(2): 8. [online] URL: http:// www.ecologyandsociety.org/vol10/iss2/art8/.

Danulat, E., and G. J. Edgar, editors. 2002. Reserva Marina de Galápagos: línea base de la biodiversidad. Fundación Charles Darwin and Servicio Parque Nacional Galápagos, Santa Cruz, Ecuador. Available online at: http://www.darwinfo undation.org/files/library/pdf/RMG-Linea-Base-Bio. pdf.

Davidson-Hunt, I. J., and F. Berkes. 2003. Nature and society through the lens of resilience: toward a human-in-ecosystem perspective. Pages 53-82 in $\mathrm{F}$. Berkes, J. Colding, and C. Folke, editors. Navigating social-ecological systems: building resilience for complexity and change. Cambridge University Press, Cambridge, UK.

de Groot, R. S. 1983. Tourism and conservation in the Galapagos Islands. Biological Conservation 26 (4):291-300.

Díaz, S., and M. Cabido. 2001. Vive la différence: plant functional diversity matters to ecosystem processes. Trends in Ecology and Evolution 16 (11):646-655.

Epler, B., and M. E. Proaño. 2007. How many tourists can Galapagos accomodate? Pages 36-41 in Galapagos Report 2006-2007. CDF, GNP, and INGALA, Puerto Ayora, Ecuador. Available online at: www.darwinfoundation.org/files/library/pdf/2008/ Galapagos Report 2006-2007 eng.pdf.
Folke, C. 2006a. The economic perspective: conservation against development versus conservation for development. Conservation Biology 20 (3):686-688.

Folke, C. 2006 b. Resilience: the emergence of a perspective for social-ecological systems analyses. Global Environmental Change 16(3):253-267.

Folke, C., S. Carpenter, B. Walker, M. Scheffer, T. Elmqvist, L. Gunderson, and C. S. Holling. 2004. Regime shifts, resilience, and biodiversity in ecosystem management. Annual Review of Ecology, Evolution and Systematics 35:557-581.

González, J. A. 2007. Cooperando en un mundo cambiante: una mirada sobre el papel de las organizaciones cooperantes en el presente y futuro de Galápagos. Pages 277-287 in P. Ospina and C. Falconí, editors. Galápagos: migraciones, economía, cultura, conflictos y acuerdos. Corporación Editora Nacional, Quito, Ecuador.

Grenier, C. 2000. Conservation contre nature. Les îles Galápagos. Collection Latitude 23, IRD Éditions, Paris, France.

Gunderson, L. H., and C. S. Holling, editors. 2002. Panarchy: understanding transformations in human and natural systems. Island Press, Washington, D.C., USA.

Heylings, P., and M. Bravo. 2007. Evaluating governance: a process for understanding how comanagement is functioning, and why, in the Galapagos Marine Reserve. Ocean and Coastal Management 50(3-4):174-208.

Holling, C. S. 2001. Understanding the complexity of economic, ecological, and social systems. Ecosystems 4(5):390-405.

Holling, C. S., and G. K. Meffe. 1996. Command and control and the pathology of natural resource management. Conservation Biology 10(2):328-337.

Instituto Nacional de Estadística y Censos. 2002. Censo nacional de población y vivienda 2001. Instituto Nacional de Estadística y Censos, Quito, Ecuador.

Jasanoff, S., R. Colwell, M. S. Dresselhaus, W. T. Golden, R. D. Goldman, M. R. C. Greenwood, A. 
S. Huang, W. Lester, S. A. Levin, M. C. Linn, J. Lubchenco, R. S. Nicholson, M. J. Novacek, A. C. Roosevelt, J. E. Taylor, and N. Wexler. 1997. Conversations with the community: AAAS at the millennium. Science 278:2066-2067.

Kates, R. W., W. C. Clark, R. Corell, J. M. Hall, C. C. Jaeger, I. Lowe, J. J. McCarthy, H. J. Schellnhuber, B. Bolin, N. M. Dickson, S. Faucheux, G. C. Gallopin, A. Grübler, B. Huntley, J. Jäger, N. S. Jodha, R. E. Kasperson, A. Mabogunje, P. Matson, H. Mooney, B. Moore III, T. O'Riordan, and U. Svedlin. 2001. Sustainability science. Science 292:641-642.

Kerr, S., S. Cárdenas, and J. Hendy. 2004. Migration and the environment in the Galapagos: an analysis of economic and policy incentives driving migration, potential impacts from migration control, and potential policies to reduce migration pressure. Motu Working Paper 03-17. Motu Economic and Public Policy Research, Wellington, New Zealand.

Kerr, S. A. 2005. What is small island sustainable development about? Ocean and Coastal Management 48(7-8):503-524.

Latorre, O. 1999. El hombre en las islas encantadas: la historia humana de Galápagos. FUNDACYT, Quito, Ecuador.

Levin, S. A. 1998. Ecosystems and the biosphere as complex adaptive systems. Ecosystems $\mathbf{1}$ (5):431-436.

Liu, J., T. Dietz, S. R. Carpenter, M. Alberti, C. Folke, E. Moran,A. N. Pell, P. Deadman, T. Kratz, J. Lubchenco, E. Ostrom, Z. Ouyang, W. Provencher, C. L. Redman, S. H. Schneider, and W. W. Taylor. 2007. Complexity of coupled human and natural systems. Science 317:1513-1516.

MacFarland, C., and M. Cifuentes. 1996. Case study: Ecuador-Galapagos. Pages 135-188 in V. Dompka, editor. Human population, biodiversity and protected areas: science and policy issues. American Association for the Advancement of Science (AAAS), Washington, D.C., USA.

Magee, J., C. K. McMullen, J. K. Reaser, E. Spitzer, S. Struve, C. Tufts, A. Tye, and G. Woodruff. 2001. Green invaders of the Galápagos Islands. Science 294:1279-1280.
Millennium Ecosystem Assessment. 2005. Ecosystems and human well-being: synthesis. Island Press, Washington, D.C., USA. Available online at: http://www.millenniumassessment.org/ documents/document.356.aspx.pdf.

Olsson, P., C. Folke, and T. Hahn. 2004. Socialecological transformation for ecosystem management: the development of adaptive co-management of a wetland landscape in southern Sweden. Ecology and Society 9(4): 2. [online] URL: http://www.ecol ogyandsociety.org/vol9/iss4/art2/.

Ospina, P. 2001. Identidades en Galápagos: el sentimiento de una diferencia. Trama, Quito, Ecuador.

Ospina, P. 2006. Galápagos, naturaleza y sociedad: actores sociales y conflictos ambientales. Universidad Andina Simón Bolívar and Corporación Editora Nacional, Quito, Ecuador.

Perry, R., editor. 1984. Galápagos. Pergamon Press, Oxford, UK.

Parque Nacional Galápagos. 2006. Plan de manejo: Parque Nacional Galápagos. Un pacto por la conservación y desarrollo sustentable del archipiélago. Ministerio del Ambiente, Quito, Ecuador. Available online at: http://www.galapago spark.org/archivos/PM PNG 2005.pdf.

Parque Nacional Galápagos. 2007. Una visión de futuro para Galápagos: el plan de manejo para todos. Parque Nacional Galápagos, Puerto Ayora, Ecuador.

Rodríguez, J. 1993. Las islas Galápagos: estructura geográfica y propuesta de gestión territorial. Abya-Yala, Quito, Ecuador.

Santander, T., W. Tapia, J. A. González, C. Montes, and E. Araujo. 2008. Tendencias generales de la investigación científica en Galápagos. In Informe Galápagos 2007-2008. PNG, FCD, and INGALA, Puerto Ayora, Ecuador. In press.

Scheffer, M., S. Carpenter, J. A. Foley, C. Folke, and B. Walker. 2001. Catastrophic shifts in ecosystems. Nature 413:591-596.

Scoones, I. 1999. New ecology and the social sciences: what prospects for a fruitful engagement? Annual Review of Anthropology 28:479-507. 
Snell, H. L., A. Tye, C. E. Causton, and R. Bensted-Smith. 2002. Current status of and threats to the terrestrial biodiversity of Galapagos. Pages 30-47 in R. Bensted-Smith, editor. 2002. A biodiversity vision for the Galapagos Islands. Charles Darwin Foundation and World Wildlife Fund, Puerto Ayora, Ecuador. Available online at: www.darwinfoundation.org/files/library/pdf/ bio vision galapagos eng.pdf.

Taylor, J. E., G. A. Dyer, M. Stewart, A. YunezNaude, and S. Ardila. 2003. The economics of ecotourism: a Galápagos Islands economy-wide perspective. Economic Development and Cultural Change 51(4):977-997.

Thompson, J. N., O. J. Reichman, P. J. Morin, G. A. Polis, M. E. Power, R. W. Sterner, C. A. Couch, L. Gough, R. Holt, D. U. Hooper, F. Keesing, C. R. Lovell, B. T. Milne, M. C. Molles, D. W. Roberts, and S. Y. Strauss. 2001. Frontiers of ecology. BioScience 51(1):15-24.

Tye, A., M. C. Soria, and M. R. Gardener. 2002. A strategy for Galapagos weeds. Pages 336-341 in C. R. Veitch and M. N. Clout, editors. Turning the tide: the eradication of invasive species. IUCN, Gland, Switzerland.

Walker, B., S. Carpenter, J. Anderies, N. Abel, G. S. Cumming, M. Janssen, L. Lebel, J. Norberg, G. D. Peterson, and R. Pritchard. 2002. Resilience management in social-ecological systems: a working hypothesis for a participatory approach. Conservation Ecology 6(1): 14. [online] URL: http ://www.consecol.org/vol6/iss1/art14/.

Walker, B., L. Gunderson, A. Kinzig, C. Folke, S. Carpenter, and L. Schultz. 2006. A handful of heuristics and some propositions for understanding resilience in social-ecological systems. Ecology and Society 11(1): 13. [online] URL: http://www.ecolog yandsociety.org/vol11/iss1/art13/.

Watkins, G., and F. Cruz. 2007. Galapagos at risk: a socioeconomic analysis of the situation in the archipelago. Charles Darwin Foundation, Puerto Ayora, Ecuador. Available online at: http://www.d arwinfoundation.org/en/library/pubs/2007/

galapagos at risk.

Wilkinson, S. R., M. A. Naeth, and F. K. A. Schmiegelow. 2005. Tropical forest restoration within Galapagos National Park: application of a state-transition model. Ecology and Society 10(1): 28. [online] URL: http://www.ecologyandsociety.org/ vol10/iss 1/art28/. 